\title{
DUAL ROLE OF TIN REACTION BARRIER IN GOLD BASED METALLIZATION TO GaAs
}

\author{
A. Piotrowska, E. Kamińska, M. Guziewicz, J. Adamczewska, \\ Institute of Electron Technology, Al. Lotników 32/46, 02-668 Warszawa, Poland
}

\section{S. KWIATKowski and A. TURos}

Institute of Nuclear Studies, Hoża 69, 00-682 Warszawa, Poland

Reactively sputtered TiN films were evaluated as annealing cap improving the formation of $\mathrm{Au}(\mathrm{Zn})$ ohmic cultact and as antidiffusion barrier protecting contact metallization and underlying $\mathrm{GaAs}$ against reaction with $\mathrm{Au}$ overlayers.

PACS numbers: $73.40 . \mathrm{Ns}$

Presenting an interesting combination of properties such as high thermal stability, high electrical conductivity and hardness, good resistance to corrosion, TiN thin films are of great interest in various applications, such as the technology of coatings resistant to severe environments and the technology of advanced metallizations for semiconductor devices [1-5]. In this paper we describe an approach for improving the reliability of multilayer gold based metallization on GaAs by applying TiN as a reaction barrier. TiN films were evaluated as: (1) an annealing cap enabling formation of improved $\mathrm{Au}(\mathrm{Zn})$ ohmic contact to $p$-GaAs, and (2) a diffusion barrier protecting contact metallization and underlying GaAs from reacting with gold overlayers used for bonding and interconnection purposes.

(100) GaAs wafers $\mathrm{Zn}$ doped to $p=1.2 \times 10^{18} \mathrm{~cm}^{-3}$ were used in the present experiments. Barrier TiN films were prepared by reactive RF bias magnetron sputtering from Ti target in a Leybold L560 Universal Coating System with the base pressure of $1.5 \times 10^{-6} \mathrm{hPa}$. Deposition was carried out in mixed $\mathrm{Ar}+\mathrm{N}_{2}$ discharges with the flow rates of the individual gas adjusted by mass flow controllers. N/Ti ratios in as deposited films were measured using $2 \mathrm{MeV} \mathrm{He}{ }^{+}$Rutherford backscattering (RBS), while X-ray diffraction was used to determine lattice parameters and preferred orientation. Four-probe method was applied to evaluate electric sheet resistance of TiN films. $\mathrm{Au}(\mathrm{Zn})$ contact metallization was deposited by sequential evaporation of $40 \mathrm{~nm} \mathrm{Au} / 40 \mathrm{~nm} \mathrm{Zn/274} \mathrm{nm} \mathrm{Au} \mathrm{layers;} \mathrm{it} \mathrm{needed} \mathrm{a} \mathrm{heat} \mathrm{treatment}$ for $3 \mathrm{~min}$ at $420^{\circ} \mathrm{C}$ to form an ohmic contact with $p$-GaAs. $150 \mathrm{~nm}$ thick Au films were used as contact overlayers.

Since the sublimation of As is a strong driving force for thermally induced reaction between $\mathrm{Au}$ and $\mathrm{GaAs}$, to prove the applicability of $\mathrm{TiN}$ as a reaction 

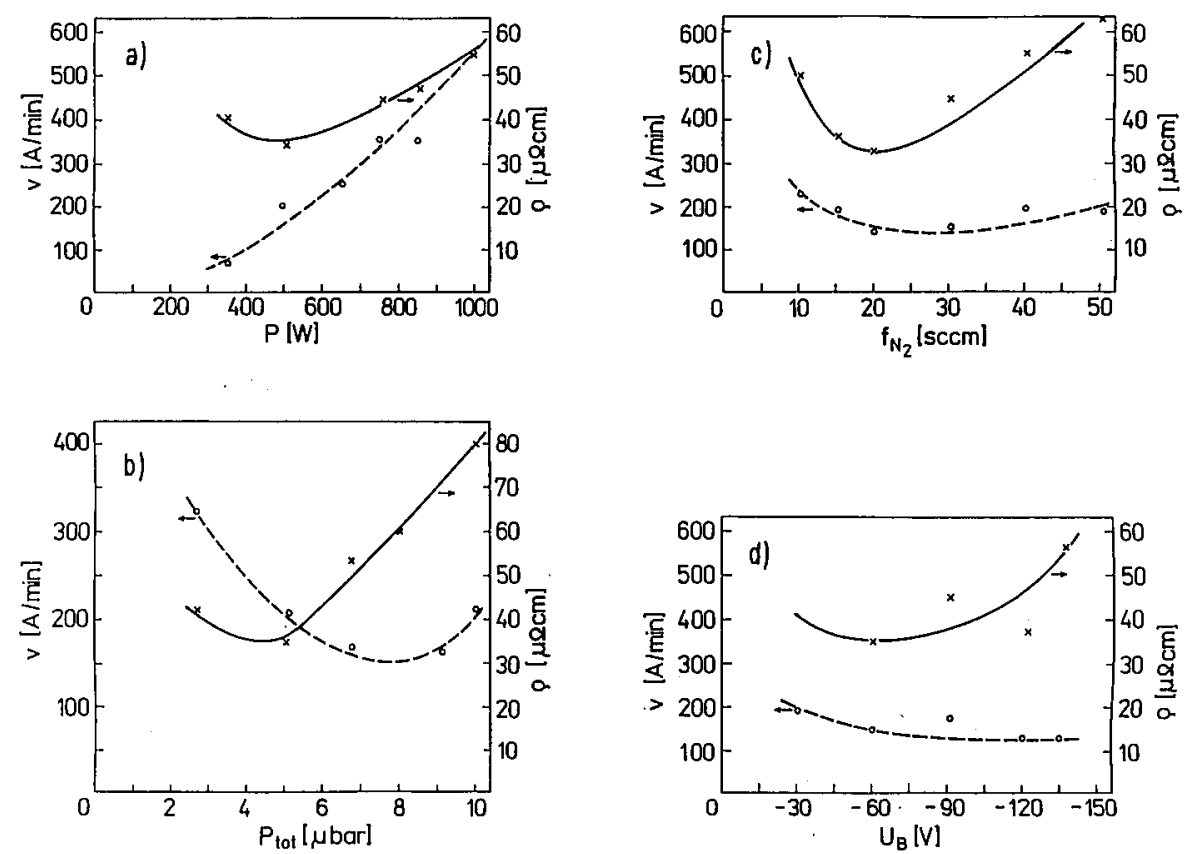

Fig. 1. The dependence of resistivity and rate of deposition of TiN films on: (a) the power applied to the plasma, (b) the total pressure, (c) the $\mathrm{N}_{2}$ flow, (d) the substrate bias voltage; $P=500 \mathrm{~W}, \mathrm{~N}_{2} / \mathrm{Ar}=0.18, f_{\mathrm{Ar}}=100 \mathrm{sccm}, U_{\mathrm{B}}=-60 \mathrm{~V}$, when constant.

barrier, in our studies, the measurements of As losses during thermal processing were of special concern. The arsenic release from $\mathrm{GaAs} / \mathrm{Au}(\mathrm{Zn}) / \mathrm{TiN}$ and $\mathrm{GaAs} / \mathrm{Au}(\mathrm{Zn}) / \mathrm{TiN} / \mathrm{Au}$ structures was examined by a Cr-collector method $[6,7]$. It consists in capturing the evaporating As species within $\mathrm{Cr} / \mathrm{SiO}_{2} / \mathrm{Si}$ collectors placed during thermal processing, face-to-face, on top of metallized GaAs surfaces. Heat treatments were carried out by means of furnace annealing under flowing $\mathrm{H}_{2}$. After annealings the content of As in the $\mathrm{Cr}$ collector films as well as the metallized GaAs samples were analyzed with RBS technique using $2 \mathrm{MeV} \mathrm{He}{ }^{+}$ions. In addition to the large area samples which were used for metallurgical studies, the patterned samples for the specific contact resistance measurements were prepared by standard photolithographic techniques.

Figure 1 shows the average deposition rate and the sheet resistance of TiN films as a function of applied parameters of reactive bias magnetron sputtering. All TiN films grown in these experiments were stoichiometric with lattice parameter $4.24 \AA$. They were polycrystalline with randomly oriented grains of the size not exceeding $1 \mu \mathrm{m}$. The most important point from these data is that adjusting growth parameters TiN films with electrical resistivity close to that of bulk material [5] can be obtained. $100 \mu \mathrm{m}$ thick TiN films deposited at $p=5.8 \times 10^{-3} \mathrm{hPa}$, $\mathrm{N}_{2} / \mathrm{Ar}=0.18, U_{\mathrm{B}}=-60 \mathrm{~V}$ and $P=500 \mathrm{~W}$ were further analyzed for their applicability as a reaction barrier. 

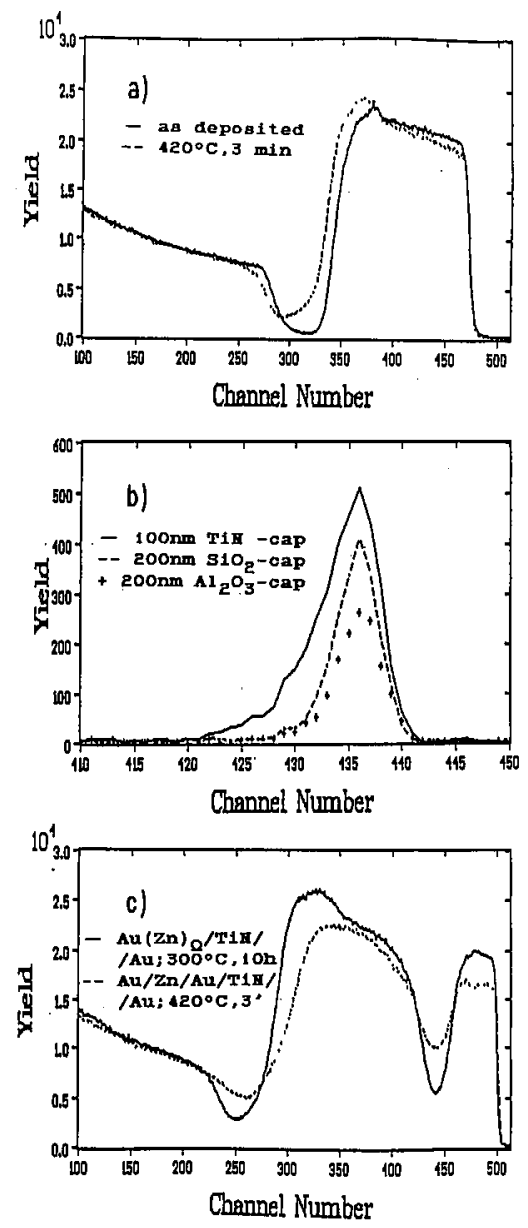

Fig. 2. $2 \mathrm{MeV}^{4} \mathrm{He}^{+} \mathrm{RBS}$ spectra of: (a) GaAs/Au/Zn/Au/TiN sample before and after annealing at $420^{\circ} \mathrm{C}$ for $3 \mathrm{~min}$, (b) $\mathrm{Si} / \mathrm{SiO}_{2} / \mathrm{Cr}$ collectors heat treated in contact with $\mathrm{GaAs} / \mathrm{Au} / \mathrm{Zn} / \mathrm{Au}$ samples capped with $\mathrm{TiN}, \mathrm{Al}_{2} \mathrm{O}_{3}$, or $\mathrm{SiO}_{2}$ films for the annealing at $420^{\circ} \mathrm{C}$ for $3 \mathrm{~min},(\mathrm{c}) \mathrm{GaAs} / \mathrm{Au}(\mathrm{Zn}) / \mathrm{TiN} / \mathrm{Au}$ contact aged for $10 \mathrm{~h}$ at $300^{\circ} \mathrm{C}$, and $\mathrm{GaAs} / \mathrm{Au} / \mathrm{Zn} / \mathrm{Au} / \mathrm{TiN} / \mathrm{Au}$ metallization annealed for $3 \mathrm{~min}$ at $420^{\circ} \mathrm{C}$.

Figures $2 \mathrm{a}$ and $2 \mathrm{~b}$ illustrate the applicability of TiN film as annealing cap during formation of $\mathrm{Au}(\mathrm{Zn})$ ohmic contact (heat treatment at $420^{\circ} \mathrm{C}$ for $3 \mathrm{~min}$ ). $200 \mathrm{~nm}$ thick RF magnetron sputtered $\mathrm{SiO}_{2}$ and $\mathrm{Al}_{2} \mathrm{O}_{3}$ caps were used for comparison. Figure 2a shows $2 \mathrm{MeV} \mathrm{He}+\mathrm{RBS}$ spectra of as deposited and heat treated $\mathrm{GaAs} / \mathrm{Au} / \mathrm{Zn} / \mathrm{Au} / \mathrm{TiN}$ metallization, in Fig. 2b the portion of RBS spectra obtained from respective $\mathrm{Cr}$ collectors is displayed. The total amount of As losses from GaAs/ $\mathrm{Au}(\mathrm{Zn})$ contact capped with TiN $\left(1.3 \times 10^{16}\right.$ at. $\left./ \mathrm{cm}^{2}\right)$ is slightly higher than for substituting insulating caps $\left(6.2 \times 10^{15}\right.$ at. $/ \mathrm{cm}^{2}$ for $\mathrm{SiO}_{2}$ and $4.4 \times 10^{15}$ 
at. $/ \mathrm{cm}^{2}$ for $\mathrm{Al}_{2} \mathrm{O}_{3}$ ), but about an order of magnitude lower than for contacts annealed without capping layer $\left(1.1 \times 10^{17} \mathrm{at} . / \mathrm{cm}^{2}\right)$ [7]. These data prove the effectiveness of TiN capping layer in suppressing the decomposition of GaAs during formation of ohmic contact. Figure 2c displays RBS spectra of multilayer $\mathrm{Au} / \mathrm{Zn} / \mathrm{Au} / \mathrm{TiN} / \mathrm{Au}$ metallization after heat treatment corresponding to the formation of ohmic contact and of the $\mathrm{Au}(\mathrm{Zn})_{\Omega} / \mathrm{TiN} / \mathrm{Au}$ structure after aging at $300^{\circ} \mathrm{C}$ for 10 hours. The respective As losses were $4.6 \times 10^{16}$ at. $/ \mathrm{cm}^{2}$ and $4.1 \times 10^{14}$ at. $/ \mathrm{cm}^{2}$, indicating that TiN films are promising antidiffusion barrier during device processing.

The specific contact resistance of $\mathrm{Au}(\mathrm{Zn})$ ohmic contact annealed under TiN cap is lower than that prepared without capping layer $\left(3.7 \times 10^{-5} \Omega \mathrm{cm}^{2}\right.$ and $6.9 \times 10^{-5} \Omega \mathrm{cm}^{2}$ respectively). TiN barrier was also found to improve aging characteristics of multilayer metallization. Contact resistance of $\mathrm{GaAs} / \mathrm{Au}(\mathrm{Zn})_{\Omega} / \mathrm{Au}$ samples increased from $3.6 \times 10^{-5} \Omega \mathrm{cm}^{2}$ to $6.3 \times 10^{-5} \Omega \mathrm{cm}^{2}$ after annealing for 10 hours at $300^{\circ} \mathrm{C}$ but did not change when TiN barrier was inserted between contact metallization and $\mathrm{Au}$ overlayer.

\section{References}

[1] H. Holleck, Surf. Coat. Technol. 43/44, 245 (1990).

[2] T.E. Tang, Ch. Wei, R.A. IIaken, T.C. Holloway, L.R. Ilite, T.G.W. Blacke, Proc. IEEE ED 34, 682 (1987).

[3] J.A. Thompson, R.D. Remba, J. Electrochem. Soc. 134, 3205 (1987).

[4] M. Taniguchi, J. Amado, T. Nemoto, K. Shinohara, IEEE Proc. 28th Ann. Reliability Physics 1990 Meeting 94, 251 (1990).

[5] J.-E. Sundgren, Thin Solid Films 128, 21 (1985).

[6] T.E. Haynes, W.K. Chu, T.L. Aselage, S.T. Picraux, Appl. Phys. Lett. 49, 666 (1986).

[7] A. Piotrowska, E. K. Kamińska, S. Kwiatkowski, A. Turos, to be published. 